Joanna Majak

Ewa Zamysłowska-Szmytke

Elżbieta Rajkowska

Mariola Śliwińska-Kowalska

\title{
AUDITORY TEMPORAL PROCESSING TESTS - NORMATIVE DATA FOR POLISH-SPEAKING ADULTS
}

\author{
TESTY SŁUCHOWEGO PRZETWARZANIA CZASOWEGO - WARTOŚCI NORMATYWNE \\ U DOROSŁYCH POSŁUGUJĄCYCH SIĘ JĘZYKIEM POLSKIM
}

Nofer Institute of Occupational Medicine / Instytut Medycyny Pracy im. prof. J. Nofera, Łódź, Poland

Audiology and Phoniatrics Clinic / Klinika Audiologii i Foniatrii

\begin{abstract}
Background: Several subjects exposed to neurotoxins in the workplace need to be assessed for central auditory deficit. Although central auditory processing tests are widely used in other countries, they have not been standardized for the Polish population. The aim of the study has been to evaluate the range of reference values for 3 temporal processing tests: the duration pattern test (DPT), the frequency pattern test (FPT) and the gaps in noise test (GIN). Material and Methods: The study included 76 normal hearing individuals ( 38 women, $38 \mathrm{men}$ ) at the age of 18 to 54 years old (mean \pm standard deviation: $39.4 \pm 9.1$ ). All study participants had no history of any chronic disease and underwent a standard ENT examination. Results: The reference range for the DPT was established at $55.3 \%$ or more of correct answers, while for the FPT it stood at $56.7 \%$ or more of correct answers. The mean threshold for both ears in the GIN test was defined as $6 \mathrm{~ms}$. In this study there were no significant associations between the DPT, FPT and GIN results and age or gender. Symmetry between the ears in the case of the DPT, FPT and GIN was found. Conclusions: Reference ranges obtained in this study for the DPT and FPT in the Polish population are lower than reference ranges previously published for other nations while the GIN test results correspond to those published in the related literature. Further investigations are needed to explain the discrepancies between normative values in Poland and other countries and adapt tests for occupational medicine purposes. Med Pr 2015;66(2):145-152
\end{abstract}

Key words: auditory temporal processing, DPT, FPT, GIN, normative values

\section{STRESZCZENIE}

Wstęp: Wiele osób pracujących w narażeniu na substancje neurotoksyczne wymaga badań w kierunku ośrodkowych zaburzeń słyszenia. Mimo że używane w tym celu testy ośrodkowego przetwarzania słuchowego sa szeroko stosowane w innych krajach, nie zostały dotąd wystandaryzowane dla populacji polskiej. Celem pracy było określenie zakresu wartości referencyjnych dla 3 testów przetwarzania czasowego: testu wzorcu długości (duration pattern test - DPT), testu wzorcu częstotliwości (frequency pattern test - FPT) i testu wykrywania przerw w szumie (gaps in nosie - GIN). Materiał i metody: Badaniami objęto 76 osób z prawidłowym słuchem (38 kobiet, 38 mężczyzn) w wieku 18-54 lata (średnia \pm odchylenie standardowe: 39,4 $\pm 9,1)$. Żaden z uczestników badania nie cierpiał w przeszłości na chorobę przewlekłą, a wynik badania otolaryngologicznego u każdego z uczestników był w normie. Wyniki: Obliczono, że przedział wartości prawidłowych dla DPT wynosi 55,3-100\%, a dla FPT - 56,7-100\% poprawnych odpowiedzi. Przybliżony średni próg detekcji dla obu uszu w teście GIN został ustalony na poziomie 6 ms. Nie stwierdzono istotnych zależności między wynikami DPT, FPT i GIN a wiekiem lub płcią. Stwierdzono symetrię DPT, FPT i GIN dla obu uszu. Wnioski: Przedziały wartości referencyjnych dla DPT i FPT w populacji polskiej są niższe niż wcześniej publikowane zakresy referencyjne dla innych narodów, natomiast wyniki GIN są zgodne z publikowanymi danymi literaturowymi. Konieczne są dalsze badania w celu wyjaśnienia rozbieżności między wartościami normatywnymi w Polsce a w innych krajach oraz dostosowanie testów do potrzeb medycyny pracy. Med. Pr. 2015;66(2):145-152

Słowa kluczowe: przetwarzanie czasowe, DPT, FPT, GIN, wartości normatywne

Corresponding author / Autorka do korespondencji: Joanna Majak, Nofer Institute of Occupational Medicine, Audiology and Phoniatrics Clinic, św. Teresy 8, 91-348 Łódź, Poland, e-mail: asiamajak@wp.pl

Received: July 21, 2014, accepted: November 6, 2014

Funding / Finansowanie: supported by the Ministry of Science and Higher Education (grant no. IMP/18.10/2013). Grant manager: prof. Mariola Śliwińska-Kowalska, MD, PhD. 


\section{INTRODUCTION}

Several occupational processes involving chemicals may cause toxic encephalopathy. Occupational exposure to toxic agents may induce adverse effects on human hearing, that are associated with cochlear pathology and dysfunction of the Central Auditory Nervous System (CANS). Although tests of the central auditory processing are widely used in other countries, they have not been standardized for the Polish-speaking population.

The Central Auditory Processing (CAP) refers to the perceptual processing of auditory information in the central nervous system (CNS) and the neurobiologic activity that underlies that processing [1]. Auditory processing disorders (APD) may be described as deficits in the effectiveness indicating how successfully the CNS utilizes auditory information, including inter-hemispheric communication [2].

According to the American Speech-Language-Hearing Association (ASHA), the APD includes the auditory mechanisms that underlie the following abilities or skills: auditory discrimination; temporal aspects of audition; sound localization and lateralization; auditory performance in competing acoustic signals and auditory performance with degraded acoustic signals. The auditory processing disorders may be diagnosed if difficulties in the processing of auditory information in the CNS are demonstrated by poor performance in one or more of the above skills [1]. The auditory temporal processing may be defined as the perception of the sound in the restricted time interval [3].

Although temporal processing is observed at many levels of the auditory pathway, it depends mainly on cortical and inter-hemispheric processing [4]. Categories of temporal processing include temporal ordering or sequencing, temporal resolution, temporal integration and temporal masking. There are no clinically available tests of temporal integration and temporal masking, so audiologists incorporate tests of temporal sequencing and temporal resolution in their clinical practice [3]. Temporal ordering and temporal resolution tests are recommended as a part of auditory processing screening test battery [1]. Time processes such as temporal sequencing and temporal resolution play a crucial role in the recognition of acoustic features of speech such as prosodic, accent and rhythm details. Temporal resolution is directly connected with speech perception, hence most patterns in speech sounds are based on millisecond time differences [3].
Temporal ordering refers to the processing of 2 or more auditory stimuli in their order of occurrence in time. The most widely used clinical tests of temporal sequencing or ordering, which gained widespread acceptance, are the duration pattern test (DPT) and the frequency pattern test (FPT) [5].

Temporal resolution refers to the shortest duration of time, in which subjects can discriminate between 2 auditory signals [3]. Temporal resolution is considered to be important for the identification of fine differences in speech signals [6].The most commonly used tests of temporal resolution measure gap detections in an ongoing sound. The gaps-in-noise test (GIN), introduced by Musiek et al., assesses the detection of silence intervals (gaps) that are embedded in white noise [7].

Even non-verbal auditory test performance may depend on language features. It has been shown that speakers of tonal languages (e.g., Chinese) have better abilities in imitating and discriminating musical pitch than speakers of non-tonal languages [8]. It has been shown that processing of duration of non-speech sounds is enhanced in the case of speakers of a quantity language (Finnish) and non-quantity language musicians (French musicians) but not in the case of non-quantity language nonmusicians [9]. According to the confounding effect of the language experience, Dillon et al. stated that clinicians of each country should elaborate their own test batteries to evaluate the APD [10].

Although there are a lot of available test batteries for English-speaking populations (e.g., the screening test for the auditory processing disorders (SCAN), the Multiple Auditory Processing Assessment (MAPA)), and a lot of work in this area has been done in non English-speaking countries [11,12], there is still a lack of auditory processing test norms in other countries, including Poland.

The aim of this study has been to evaluate the range of reference values of the DPT, FPT and GIN and to check gender, age and ear symmetry dependence on the performance on these tests in normal hearing individuals.

\section{MATERIAL AND METHODS}

\section{Subjects}

Initially, the study sample included 100 participants with no history of chronic disease and standard ENT examination. In the 1st stage of the study a detailed medical history was taken. Subjects were asked particularly about their history of ear disease, subjective hearing deterioration, difficulties to understand speech in noisy environments, exposure to noise and organic solvents, 
and language or learning disabilities. Only individuals reporting absence of the problems mentioned above were included in the study. Subsequently, the ENT examination and pure-tone audiometry (PTA) was carried out. In a sound-proof booth hearing thresholds were obtained at $250-8000 \mathrm{~Hz}$ for air conduction and $500-4000 \mathrm{~Hz}$ for bone conduction. Only participants with bilateral hearing thresholds equal to or better than $20 \mathrm{~dB} H \mathrm{HL}$ at all tested frequencies were included in the study group.

According to Musiek et al., before carrying out the temporal processing tests, the usage of practice items is needed $[13,14]$. Thus, before each test administration initial practice was used to verify if the subject had understood the idea of the test. The scores in this initial task were not included in the total test results.

Based on the initial criteria, 24 subjects were excluded from the study: 2 subjects - due to the history of health problems as mentioned above, 15 subjects - due to abnormal PTA results and 4 individuals - due to abnormal initial practice testing. The final group comprised 76 normal hearing individuals ( 38 women and 38 men) at the age of 18 to 54 years old (mean \pm standard deviation: $39.4 \pm 9.1$ ).

\section{Methods}

Temporary processing tests (DPT, FPT and GIN) were taken monaurally on each person, and were performed in a quiet room after making the subject familiar with each task.

\section{The duration pattern test}

The duration pattern test was conducted by using a commercially available compact disc from Auditec, St. Louis. In this study, a set of 30 sequences of 2 tones differing in their duration ( $250 \mathrm{~ms}$ and $500 \mathrm{~ms}$ ), arranged in 3-tone tokens, were presented monaurally to each ear (at $50 \mathrm{~dB}$ HL above the subject's threshold for $1000 \mathrm{~Hz}$ in the PTA). The tone frequency was $1000 \mathrm{~Hz}$ with a rise/fall time of $10 \mathrm{~ms}$, and with an inter-tone interval of $300 \mathrm{~ms}$. Subjects were asked to verbalize the duration of each tone in the sequence (e.g., "short-long-long"). The answers were registered on the score sheet and the percentage rate of correct answers was calculated.

\section{The frequency pattern test}

The frequency pattern test was conducted by using a commercially available compact disc from Auditec, St. Louis. In this study, a set of 30 sequences of 2 tones differing in their pitch $(880 \mathrm{~Hz}$ and $1122 \mathrm{~Hz})$, arranged in 3-tone tokens, was presented monaurally to each ear (at $50 \mathrm{~dB}$ HL above the subject's threshold at $1000 \mathrm{~Hz}$ in the PTA). The tone duration was $150 \mathrm{~ms}$ with a rise/ fall time of $10 \mathrm{~ms}$, and with an inter-tone interval of $200 \mathrm{~ms}$. Subjects were asked to name the pitch of each tone in the sequence (e.g., "high-low-high"). The answers were registered on the score sheet and the percentage rate of correct answers was calculated.

\section{The gaps in noise test}

The gaps in noise test was conducted by using a commercially available compact disc from Auditec, St. Louis. Stimuli were presented monaurally at $50 \mathrm{~dB}$ HL above the subject's threshold at $1000 \mathrm{~Hz}$ in the PTA. This test consisted of series of 36 different 6 -s segments of white noise, each containing $0-3$ gaps. The inter-stimulus interval between noise segments was $5 \mathrm{~s}$. The gap durations in this test were (ms): 2, 3, 4, 5, 6, 8, 10, 12 and 20 with each silence gap duration occurring 6 times. The test contained a total of 60 gaps per list. While undergoing the test, the subject was required to listen for any silence gap that might or might not occur within each noise segment. As soon as the noise segment was finished the subject had to respond how many gaps (0-3) were contained in the segment of noise that was presented.

The approximate threshold was used for analysis by considering the following 2 criteria:

1. At least 4 out of 6 gaps are correctly identified.

2. Performance for longer gap durations is not worse than 4 out of 6 gaps correctly identified.

There are 2 possible ways of analyzing the GIN results - the approximate threshold (ATh) and the overall percent of correct answers. The approximate threshold is preferred by the test authors because of having better sensitivity and specificity [7]. False positive responses were counted and subtracted from the number of gap durations identified per ear when more than 2 false responses occurred.

The study was approved by the Medical Ethical Committee of the Nofer Institute of Occupational Medicine, Łódź, Poland.

\section{Statistical methods}

The percentage rate of correct answers in the case of the DPT, FPT and GIN were analyzed independently for left and right ears. In the 1st step, distributions of study variables were tested. Since, a skewed distribution was clearly visible, median values (with 10th and 90th percentile) were chosen as adequate central tendency (distribution) (see Figure 1 and Table 1). Results above 10th percentile were defined as reference for the DPT and FPT, results above 90th percentile were defined as reference 
scores for the GIN. To compare the GIN results with other literature data, mean \pm 2 standard deviations were additionally calculated.
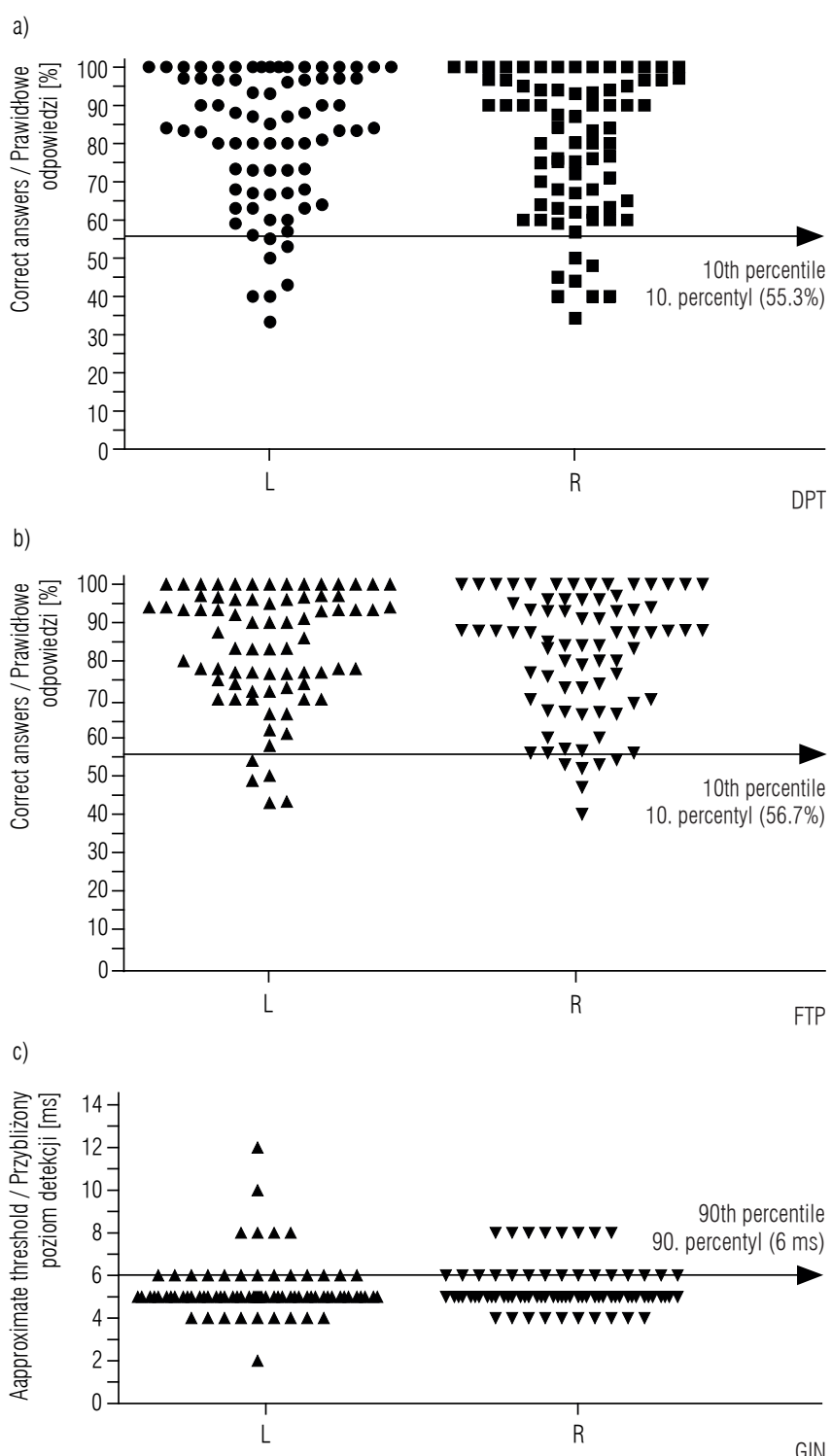

L - left ear / ucho lewe, R - right ear / ucho prawe.

DPT - duration pattern test / test wzorca długości, FPT - frequency pattern test / test wzorca częstotliwości, GIN - gaps-in-noise test / test wykrywania przerw w szumie.

Fig. 1. Results of DPT, FPT and GIN tests in both ears

Ryc. 1. Wyniki testów DPT, FPT i GIN dla obojga uszu

\section{RESULTS}

Taking into account 10th percentile, the DPT reference cut-offs were $49.4 \%, 55.7 \%$ and $55.3 \%$ for right, left and both ears, respectively (Table 1 and Figure 1A). Taking into account 10th percentile, the FPT reference cut-offs were $56 \%, 61.7 \%$ and $56.7 \%$ for right, left and both ears, respectively (Table 1 and Figure 1A). Reference cut-offs for the GIN, defined in 90th percentile, were 8,6 and 6 for right, left and both ears, respectively (Table 1 and Figure 1C).

To compare our results with the studies of other authors we additionally assessed the GDT normative values using mean \pm 2 standard deviations. The mean GDT in our study stood at $5.3 \mathrm{~ms}$ for the left ear $(<7.9$ as normative value taking into account 2 standard deviations) and $5.4 \mathrm{~ms}$ for the right ear $(<7.6$ as normative value taking into account 2 standard deviations).

There were no significant associations between the DPT/ FPT/GIN results and age (Table 2) and gender (Table 3). We showed a significant linear correlation between the left and right ear in the case of the DPT (Spearman coefficient: 0.83), the FPT (Spearman coefficient: 0.63) and the GIN (Spearman coefficient: 0.69). A significant correlation between the DPT and FPT results for both ears was observed (Table 2).

\section{DISCUSSION}

Since there were no reference values available for the Polish population, in this study we have estimated the results of 3 temporal processing tests (DPT, FPT and GIN) in 76 normal hearing Polish adult subjects.

The duration pattern test was firstly administrated by Musiek et al. in 1990 [14]. The authors showed that sensitivity and specificity of this test with respect to cerebral lesions was at the level of $83 \%[13,14]$. It indicates that this test may be a valuable method for the evaluation of the central auditory dysfunction.

The frequency pattern test was firstly described in 1972 by Pinheiro and Ptacek [15]. Similarly to the DPT its sensitivity and specificity with respect to cerebral lesions were high and were estimated respectively at $86 \%$ and $92 \%$ with respect to cerebral lesions [15]. As in other studies, both pattering tests in this study were administrated monaurally.

The gaps-in-noise test was firstly administrated by Musiek et al. in 2005, but its value in the evaluation of cerebral lesions has not been established so far [7].

\section{Reference values}

The tests scores did not follow a normal distribution in this study, which is also reported by other authors $[11,12,16]$. For that reason norms for tests in our study are suggested to be 10th percentiles as cut-off scores to distinguish between "normal" and "abnormal" results for pattern tests and results above 90th percentile have been defined as reference scores for the GIN. 
Table 1. Central tendency and distribution of study variables

Tabela 1. Centralne miary położenia i miary rozproszenia badanych zmiennych

\begin{tabular}{|c|c|c|c|c|c|c|c|c|c|}
\hline \multirow{3}{*}{$\begin{array}{l}\text { Parameter } \\
\text { Parametr }\end{array}$} & \multicolumn{6}{|c|}{$\begin{array}{c}\text { Correct answers } \\
\text { Prawidłowe odpowiedzi } \\
{[\%]}\end{array}$} & \multirow{2}{*}{\multicolumn{3}{|c|}{$\begin{array}{l}\text { GIN } \\
{[\mathrm{ms}]}\end{array}$}} \\
\hline & \multicolumn{3}{|c|}{ DPT } & \multicolumn{3}{|c|}{ FPT } & & & \\
\hline & $\mathrm{L}$ & $\mathrm{R}$ & $\begin{array}{c}\text { total } \\
\text { ogółem }\end{array}$ & $\mathrm{L}$ & $\mathrm{R}$ & $\begin{array}{c}\text { total } \\
\text { ogółem }\end{array}$ & $\mathrm{L}$ & $\mathrm{R}$ & $\begin{array}{c}\text { total } \\
\text { ogółem }\end{array}$ \\
\hline Observations / Obserwacje [n] & 76 & 76 & 152 & 76 & 76 & 152 & 76 & 76 & 152 \\
\hline Minimal value / Wartość minimalna & 33.30 & 36.00 & 33.30 & 43.00 & 40.00 & 40.00 & 2.00 & 4.00 & 2.00 \\
\hline 25th percentile / 25 . percentyl & 67.20 & 63.50 & 66.70 & 74.00 & 69.20 & 72.20 & 5.00 & 5.00 & 5.00 \\
\hline Median / Mediana & 84.00 & 83.30 & 83.60 & 88.30 & 86.60 & 86.60 & 5.00 & 5.00 & 5.00 \\
\hline 75th percentile / 75. percentyl & 97.00 & 96.20 & 96.70 & 96.40 & 95.70 & 96.00 & 5.75 & 6.00 & 6.00 \\
\hline Maximal value / Wartość maksymalna & 100.00 & 100.00 & 100.00 & 100.00 & 100.00 & 100.00 & 12.00 & 8.00 & 12.00 \\
\hline 10th percentile / 10. percentyl & 55.70 & 49.40 & 55.30 & 61.70 & 56.00 & 56.70 & 4.00 & 4.00 & 4.00 \\
\hline 90th percentile / 10. percentyl & 100.00 & 100.00 & 100.00 & 100.00 & 100.00 & 100.00 & 6.00 & 8.00 & 6.00 \\
\hline Mean / Średnia & 81.30 & 79.20 & 80.20 & 83.60 & 81.40 & 82.50 & 5.30 & 5.40 & 5.40 \\
\hline Standard deviation / Odchylenie standardowe & 17.80 & 18.60 & 18.20 & 15.20 & 16.10 & 15.70 & 1.33 & 1.07 & 1.20 \\
\hline Standard error / Błąd standardowy & 2.04 & 2.13 & 1.47 & 1.74 & 1.85 & 1.27 & 0.15 & 0.12 & 0.097 \\
\hline
\end{tabular}

Abbreviations as in Figure 1 / Skróty jak na rycinie 1.

Table 2. Linear correlation between DPT, FPT and GIN results in both ears, and age of participants*

Tabela 2. Korelacja liniowa między wynikami testów DPT, FPT i GIN w obu uszach i wiekiem badanych pacjentów

\begin{tabular}{|c|c|c|c|c|c|c|c|c|c|c|}
\hline \multirow[t]{2}{*}{ Test } & \multirow{2}{*}{$\begin{array}{c}\text { Age } \\
\text { [years] } \\
\text { Wiek } \\
\text { [w latach] }\end{array}$} & \multicolumn{9}{|c|}{$\begin{array}{l}\text { Linear correlation } \\
\text { Korelacja liniowa }\end{array}$} \\
\hline & & $\mathrm{DPT}(\mathrm{L})$ & $\mathrm{DPT}(\mathrm{R})$ & DPT & $\mathrm{FPT}(\mathrm{L})$ & $\mathrm{FPT}(\mathrm{R})$ & FPT & $\mathrm{GIN}(\mathrm{L})$ & GIN(R) & GIN \\
\hline \multicolumn{11}{|l|}{ DPT(L) } \\
\hline $\mathrm{R}$ & 0.112 & 1 & - & _- & _- & - & - & - & - & - \\
\hline $\mathrm{P}$ & 0.335 & - & - & - & - & - & - & - & - & - \\
\hline \multicolumn{11}{|l|}{$\mathrm{DPT}(\mathrm{R})$} \\
\hline $\mathrm{R}$ & 0.156 & 0.830 & 1 & - & - & - & - & - & - & - \\
\hline $\mathrm{P}$ & 0.177 & $<0.001$ & - & - & - & - & - & - & - & - \\
\hline \multicolumn{11}{|l|}{ DPT } \\
\hline $\mathrm{R}$ & 0.112 & 1 & 0.830 & 1.000 & - & - & - & - & - & - \\
\hline $\mathrm{P}$ & 0.335 & - & $<0.001$ & - & - & - & - & - & - & - \\
\hline \multicolumn{11}{|l|}{$\mathrm{FPT}(\mathrm{L})$} \\
\hline $\mathrm{R}$ & -0.126 & 0.204 & 0.274 & 0.204 & 1 & - & - & - & - & - \\
\hline $\mathrm{P}$ & 0.280 & 0.077 & 0.017 & 0.077 & - & - & - & - & - & - \\
\hline \multicolumn{11}{|l|}{$\mathrm{FPT}(\mathrm{R})$} \\
\hline $\mathrm{R}$ & -0.031 & 0.229 & 0.283 & 0.229 & 0.634 & 1 & - & - & - & - \\
\hline $\mathrm{P}$ & 0.788 & 0.047 & 0.013 & 0.047 & $<0.001$ & - & - & - & - & - \\
\hline \multicolumn{11}{|l|}{ FPT } \\
\hline $\mathrm{R}$ & -0.126 & 0.204 & 0.274 & 0.253 & 1 & 0.634 & 1 & - & - & - \\
\hline $\mathrm{P}$ & 0.280 & 0.077 & 0.017 & 0.002 & - & $<0.001$ & - & - & - & - \\
\hline \multicolumn{11}{|l|}{$\mathrm{GIN}(\mathrm{L})$} \\
\hline $\mathrm{R}$ & 0.049 & -0.128 & -0.094 & -0.128 & -0.139 & -0.165 & -0.139 & 1.000 & - & - \\
\hline $\mathrm{P}$ & 0.672 & 0.271 & 0.417 & 0.271 & 0.231 & 0.155 & 0.231 & - & - & - \\
\hline \multicolumn{11}{|l|}{$\mathrm{GIN}(\mathrm{R})$} \\
\hline $\mathrm{R}$ & -0.051 & -0.211 & -0.165 & -0.211 & -0.092 & -0.121 & -0.092 & 0.694 & 1 & - \\
\hline $\mathrm{P}$ & 0.663 & 0.068 & 0.155 & 0.068 & 0.430 & 0.298 & 0.430 & $<0.001$ & - & - \\
\hline \multicolumn{11}{|l|}{ GIN } \\
\hline $\mathrm{R}$ & 0.049 & -0.128 & -0.094 & -0.155 & -0.139 & -0.165 & -0.134 & 1 & 0.694 & 1.000 \\
\hline $\mathrm{P}$ & 0.672 & 0.271 & 0.417 & 0.056 & 0.231 & 0.155 & 0.099 & - & $<0.001$ & - \\
\hline
\end{tabular}

$\mathrm{R}$ - correlation coefficient / współczynnik korelacji, P - probability / prawdopodobieństwo.

Other abbreviations as in Figure 1 / Inne skróty jak na rycinie 1.

* Data is presented with Spearman coefficient / Dane przedstawiono przy pomocy współczynników korelacji Spearmana. 
Table 3. Associations between DPT, FPT and GIN results in both ears and gender of participants Tabela 3. Zależność między wynikami testów DPT, FPT i GIN w obu uszach a płcią badanych

\begin{tabular}{|c|c|c|c|c|c|c|c|}
\hline \multirow{2}{*}{ Test } & \multicolumn{3}{|c|}{$\begin{array}{l}\text { Females } \\
\text { Kobiety }\end{array}$} & \multicolumn{3}{|c|}{$\begin{array}{c}\text { Males } \\
\text { Mężczyźni }\end{array}$} & \multirow{2}{*}{$\mathrm{p}$} \\
\hline & $\mathrm{Me}$ & $\begin{array}{l}\text { lower quartile } \\
\text { dolny kwartyl }\end{array}$ & $\begin{array}{l}\text { upper quartile } \\
\text { górny kwartyl }\end{array}$ & $\mathrm{Me}$ & $\begin{array}{l}\text { lower quartile } \\
\text { dolny kwartyl }\end{array}$ & $\begin{array}{l}\text { upper quartile } \\
\text { górny kwartyl }\end{array}$ & \\
\hline $\operatorname{DPT}(\mathrm{L})$ & 83.65 & 73.0 & 97.0 & 85.0 & 67 & 97 & 0.7979 \\
\hline $\mathrm{DPT}(\mathrm{R})$ & 90.00 & 63.3 & 96.6 & 78.5 & 65 & 94 & 0.5557 \\
\hline DPT & 83.65 & 73.0 & 97.0 & 85.0 & 67 & 97 & 0.7979 \\
\hline $\mathrm{FPT}(\mathrm{L})$ & 91.50 & 77.0 & 96.6 & 83.0 & 72 & 96 & 0.3093 \\
\hline $\mathrm{FPT}(\mathrm{R})$ & 86.60 & 70.0 & 94.0 & 84.0 & 67 & 96 & 0.508 \\
\hline FPT & 91.50 & 77.0 & 96.6 & 83.0 & 72 & 96 & 0.3093 \\
\hline GIN(L) & 5.00 & 5.0 & 6.0 & 5.0 & 5 & 5 & 0.3801 \\
\hline GIN(R) & 5.00 & 5.0 & 6.0 & 5.0 & 5 & 5 & 0.1228 \\
\hline GIN & 5.00 & 5.0 & 6.0 & 5.0 & 5 & 5 & 0.3801 \\
\hline
\end{tabular}

Me - median / mediana.

Other abbreviations as in Figure 1 / Inne skróty jak na rycinie 1.

Other researchers have used the same boundary criteria for pattering tests (10th percentile to distinguish between "normal" and "abnormal" results) $[11,12,16]$, however in the literature, authors define the GIN results using mean \pm 2 standard deviations as cut-off scores to distinguish between "normal" and "abnormal" results $[7,16-18]$.

Normative values for the DPT, published by Musiek at al. [13], have been established at $70 \%$ or more of correct answers. Reference values for the FPT, according to Musiek et al., have been reported to stand at $75 \%$ or more of correct answers [13]. Fuente at al., whose study included 40 normal hearing Chilean adults at the age of 18 to 50 years old, established the reference range at the level of $85.5 \%$ or more of correct answers for the DPT, and $80 \%$ or more of correct answers for the FPT [11]. The results of Neijenhuis et al. in the study which included 28 Dutch adults with normal hearing at the age of 18 to 47 years old, were $90 \%$ for the DPT and $89 \%$ for the FPT [12]. In the study of Neijenhuis et al. [12] tones in both pattern tests were presented binaurally, while Musiek et al. [13], Fuente et al. [11] and authors of this research used monaural tone presentation. Norms established in this study are significantly lower (55.3\% for the DPT and $56.7 \%$ for the FPT) in comparison to studies mentioned above. One of the reasons for that fact may be a slightly different methodology used in our study than in previous investigations. In the case of the FPT, Fuente et al. used higher pitch of one of the tones $(1430 \mathrm{~Hz}$ in comparison to $1122 \mathrm{~Hz}$ used in this study), so tones were easier to distinguish. Neijenhuis et al. and Fuente et al. $[11,12]$ used a relatively low num- ber of subjects as compared to our study. It may be hypothesized that the ceiling effect in the DPT and the FPT results observed in those studies was due to the extent of the training prior to the test performance.

The fact that reference ranges obtained in this study for the DPT and the FPT in the Polish population are lower than reference ranges previously published for speakers of other languages demands further investigation.

Norms for the GIN, published by Musiek et al., were suggested to be the mean ATh at $4.8 \mathrm{~ms}$ for the left ear and $4.9 \mathrm{~ms}$ for the right ear [7]. Musiek et al. used mean \pm 2 standard deviations as cut-off scores to distinguish between "normal" and "abnormal" results. The GDT in our study defined as 90th percentile stands at $6 \mathrm{~ms}$ for the left ear and $8 \mathrm{~ms}$ for the right ear. The mean ATh for both ears defined as 90th percentile stands at $6 \mathrm{~ms}$. The mean GDT in our study defined as mean \pm 2 standard deviations stands at $5.3 \mathrm{~ms}$ for the left ear and $5.4 \mathrm{~ms}$ for the right ear. Samelli and Schochat assessed the mean GDT to stand at $4.19 \mathrm{~ms}$ [16]. In the study of Zaidan et al. the GDT standing at $4.88 \mathrm{~ms}$ (left ear) and 5.38 ms (right ear) were reported [17]. In the study of Helfer and Vargo [18] the mean ATh stood at $4.4 \mathrm{Z2} \mathrm{ms}$ for a younger group and $4.92 \mathrm{~ms}$ for an older group. Results obtained in this study correspond to those ones found in the literature.

\section{Age}

In this study there were no significant associations between the DPT, FPT results and age, which is in accordance with other authors $[10,11,13]$. 
Similarly, there were no significant associations between the GIN results and age in this study. However literature data related to this test is equivocal. According to Musiek et al. [7] the GIN stimulus simplicity (broadband noise) causes that differences due to age are unlikely. A study of these authors confirmed no significant difference on the GIN performance between young and middle-aged subjects. However, there are studies that have indicated the higher GDTs in the case of older subjects in comparison to younger control subjects $[19,20]$. Although, other investigators have questioned this finding [21]. Lister et al. [22] and He et al. [20] have not found any significant difference between the GDTs in the case of young and middle-aged individuals, either. On the other hand, results of the study of Helfer and Vargo have documented a difference in the GIN results in the case of younger and middle-aged women [18]. Probably these results are connected with a small amount of high-frequency hearing loss in the older group in that study. Previous studies have demonstrated a connection between high-frequency hearing loss and reduced gap detection ability $[23,24]$.

\section{Gender}

We did not find statistically significant differences between males and females in the FPT, DPT and GIN results, which had also been the case with the studies of Musiek et al. [6,13]. On the other hand, in the study of Samelli and Schochat, which included 100 Brazilian adults, male participants indicated a significantly better GDT than women in the GIN test [16]. Zaidan et al. also found a better GIN performance in the case of males. However, the male participants were music therapy students, which can justify the sex differences in this study [17].

\section{Ear symmetry}

Results from this investigation demonstrate symmetry between the ears in the DPT, FPT and GIN, which corresponds to the results reported in other papers [7,11-13].

The elaboration of Polish normative values for the DPT, FPT and GIN is very important for introduction of these tests to the occupational medicine practice. Studies have shown that the auditory temporal processing can be impaired in subjects exposed, among others, to industrial solvents [25]. The most ototoxic substance was styrene [26]. The results of the DPT, FPT, Hearing in Noise Test (HINT), Random Gap Detection Test (RGDT, similar to GIN), filtered speech (FS) were significantly worse in the case of normal hearing subjects exposed to organic solvents as compared to not exposed individuals [26]. Further studies are needed to implement the temporal processing tests for occupational medicine purposes.

\section{CONCLUSIONS}

1. The reference ranges obtained in this study for the DPT and FPT in the Polish-speaking population are lower than the reference ranges previously published for speakers of other languages, which demands further investigation.

2. Normative values for the GIN obtained in this study are in accordance to those found in the literature.

3. Age, gender and ear symmetry did not influence the results of any of these tests.

4. Further studies are needed to implement the temporal processing tests for occupational medicine purposes.

\section{REFERENCES}

1. American Speech-Language-Hearing Association. (Central) Auditory Processing Disorders. Working group on auditory processing disorders; 2005. Technical report [cited 2010 Oct 6]. Available from: http://www.asha.org/ policy/tr2005-00043.htm.

2. Katz J. Classification of auditory processing disorders. In: Katz J, Stecker N, Henderson D, editors. Central auditory processing: A transdisciplinary view. Chicago: Mosby Yearbook; 1992. p. 81-92.

3. Shinn JB. Temporal processing and temporal pattering tests. In: Musiek FE, Chermak GD, editors. Handbook of central auditory processing disorder. San Diego: Plural Publishing; 2007. p. 231-56.

4. Frisina RD. Subcortical neural coding mechanisms for auditory temporal processing. Hear Res. 2001;158(1-2): 1-27, http://dx.doi.org/10.1016/S0378-5955(01)00296-9.

5. Emanuel DC. The auditory processing battery: Survey of common practices. J Am Acad Audiol. 2002;13(2): 93-117.

6. Moore B. An introduction to the psychology of hearing. New York: Academic Press; 2003. p. 163-77.

7. Musiek FE, Shinn JB, Jirsa R, Bamiou DE, Baran JA, Zaida E. GIN (gaps-in-noise) test performance in subjects with confirmed central auditory nervous system involvement. Ear Hear. 2005 Dec;26(6):608-18, http:// dx.doi.org/10.1097/01.aud.0000188069.80699.41.

8. Bidelman GM, Gandour JT, Krishnan A. Cross-domain effects of music and language experience on the representation of pitch in the human auditory brainstem. 
J Cogn Neurosci. 2011;23(2):425-34, http://dx.doi.org/ 10.1162/jocn.2009.21362.

9. Marie C, Kujala T, Besson M. Musical and linguistic expertise influence pre-attentive and attentive processing of non-speech sounds. Cortex. 2012;48(4):447-57, http://dx.doi.org/10.1016/j.cortex.2010.11.006.

10. Dillon H, Cameron S, Glyde H, Wilson W, Tomlin D. An opinion on the assessment of people who may have an auditory processing disorder. J Am Acad Audiol. 2012;23(2):97-105.

11. Fuente A, McPherson B. Auditory processing tests for Spanish-speaking adults: An initial study. Int J Audiol. 2006;45(11):645-59, http://dx.doi.org/ $10.1080 / 14992020600937238$.

12. Neijenhuis KAM, Stollman MHP, Snik Ad FM, van der Broek P. Development of a central auditory test battery for adults. Int J Audiol. 2001;40(2):69-77, http://dx.doi.org/10.3109/00206090109073102.

13. Musiek FE. Frequency (pitch) and duration pattern tests. J Am Acad Audiol. 1994 Jul;5(4):265-8.

14. Musiek FE, Baran JA, Pinheiro ML. Duration pattern recognition in normal subjects and patients with cerebral and cochlear lesions. Int J Audiol. 1990;29(6): 304-13, http://dx.doi.org/10.3109/00206099009072861.

15. Pinheiro ML, Ptacek PH. Reversals in the perception of noise and tone patterns. J Acoust Soc Am. 1971 Jun;49(6):1778-83, http://dx.doi.org/10.1121/ 1.1912581.

16. Samelli AG, Schochat E. The gaps-in-noise test: Gap detection threshold in normal-hearing young adults. Int J Audiol. 2008;47(5):238-45, http://dx.doi. org/10.1080/14992020801908244.

17. Zaidan E, Garcia AP, Tedesco ML, Baran JA. [Performance of normal young adults in two temporal resolution tests]. Pro Fono. 2008;20(1):19-24. Portuguese.
18. Helfer KS, Vargo M. Speech recognition and temporal processing in middle-aged women. J Am Acad Audiol. 2009 Apr;20(4):264-71, http://dx.doi.org/10.3766/ jaaa.20.4.6.

19. Bertoli S, Smurzynski J, Probst R. Temporal resolution in young and elderly subjects as measured by mismatch negativity and a psychoacoustic gap detection task. Clin Neurophysiol. 2002;113(3):396-406, http:// dx.doi.org/10.1016/S1388-2457(02)00013-5.

20. He N-J, Horwitz AR, Dubno JR, Mills JH. Psychometric functions for gap detection in noise measured from young and aged subjects. J Acoust Soc Am. 1999;106:966-78, http://dx.doi.org/10.1121/1.427109.

21. Moore BCJ, Peters RW, Glasberg BR. Detection of temporal gaps in sinusoids by elderly subjects with and without hearing loss. J Acoust Soc Am. 1992;92:1923-32, http://dx.doi.org/10.1121/1.405240.

22. Lister J, Besing J, Koehnke J. Effects of age and frequency disparity on gap discrimination. J Acoust Soc Am. 2002;111:2793-800, http://dx.doi.org/10.1121/1.1476685.

23. Fitzgibbons PJ, Wightman FL. Gap detection in normal and hearing-impaired listeners. J Acoust Soc Am. 1982;72:761-5, http://dx.doi.org/10.1121/1.388256.

24. Grose JH, Hall III JW, Buss E. Temporal processing deficits in the pre-senescent auditory system. J Acoust Soc Am. 2006;119:2305-15, http://dx.doi. org/10.1121/1.2172169.

25. Fuente A, McPherson B, Hickson L. Auditory dysfunction associated with solvent exposure. BMC Public Health. 2013 Jan;16:13-39, http://dx.doi.org/10. 1186/1471-2458-13-39.

26. Zamyslowska-Szmytke E, Fuente A, Niebudek-Bogusz E, Sliwinska-Kowalska M. Temporal processing disorder associated with styrene exposure. Audiol Neurotol. 2009;14(5):296-302, http://dx.doi.org/10.1159/000212108. 